\title{
The Influence of the Pastor's Ability according to Ephesians 4:1-16 on the Spiritual Maturity of the Baptist Church Congregations in the Yogyakarta Region
}

\author{
Yosua Budi Ristiono, Hana Suparti, Paulus Sentot Purwoko and Timotius Sukarna
}

\section{ABSTRACT}

The shepherd has a very important role in God's purpose for His church. A shepherd should have the equipping ability as described in Ephesians 4:12a. This ability is manifested in two ways, namely: equipping the congregation with knowledge and experience of faith. The process of equipping the congregation will lead the Lord's congregation to spiritual maturity which is characterized by the unity of the spirit, the correct knowledge of the Son of God, full maturity and a level of growth that is in accordance with the fullness of Christ. The results of the research conducted using the quantitative research method concluded that the ability of the pastor to equip the congregation based on Ephesians 4:1-16 had a significant effect on the spiritual maturity of the Baptist church congregations in the Special Region of Yogyakarta.

Keywords: Equip, shepherd, spiritual maturity.
Published Online: October 14, 2021

ISSN: $2736-5514$

DOI : $10.24018 /$ theology.2021.1.5.42

\section{Y. B. Ristiono*}

STT KADESI Yogyakarta, Indonesia.

(e-mail: budi.ristiono@gmail.com)

H. Suparti

STT KADESI Yogyakarta, Indonesia.

(e-mail: hanakadesi@gmail.com)

P. S. Purwoko

STT KADESI Yogyakarta, Indonesia.

(e-mail: paksentot@gmail.com)

T. Sukarna

STT KADESI Bogor, Indonesia.

(e-mail: timotiussukarna@gmail.com)

*Corresponding Author

\section{INTRODUCTION}

God's congregation consisting of believers is the body of Christ which is expected to continue to grow towards spiritual maturity. So that the church can grow spiritually, according to Ephesians 4:11 the Lord Jesus gave five ministry gifts to His church, namely apostles, prophets, evangelists, shepherds and teachers. These are His tools to perfect the church on earth [1].

One of the five ministry gifts in Ephesians 4:11 the pastor has a very important role in God's purpose for His church. Christ who is the Apostle, Prophet, Evangelist and Teacher. All ministries are in Him. But He has one heartbeat in all of them, namely the heart of a shepherd. Therefore all ministry regardless of calling and placement in the body, should have and be motivated by the heart of a shepherd [2]. Pastoral ministry in Greek often uses the following terms: the word poimen is translated 17 times pastor and pastor once; poimaino which is translated to keep as a shepherd, or to shepherd, is also translated to give, to control; poimnetranslatedcollections, folds; poimnion translated as a flock of sheep; bosko is translated to feed, let eat grass, animal food, herd. These words together, indicate that a shepherd is one who cares for or herds a flock of sheep; feed, give instructions [3]. Functions, duties and roles of the pastor of the congregation as: pastoral ministry leader, spiritual father for the congregation, worship leader, education coordinator, builder and leader of church organizations, gospel preaching leader, and church representative for dealings with outside the church [4].

A shepherd should have the equipping ability as described in Ephesians 4:12a. This ability is manifested in two ways, namely: first, equipping the congregation with knowledge including: knowing Christ (Ephesians 4:20) and teaching the truth in Christ (Ephesians 4:21b); second, equipping the congregation with experiences of faith, including: experiences of repentance (Ephesians 4:22-24) when experiencing a renewal of life in Christ and experiences of witnessing about Christ (Ephesians 4:21a) so that more people hear about Christ. The process of equipping the congregation will bring God's congregation to spiritual maturity which is marked by the unity of the spirit, the true knowledge of the Son of God, full maturity and a level of growth that is in accordance with the fullness of Christ. Unity of the Spirit is a good means to produce unity of faith [5]. The Apostle Paul in Ephesians 4:4 mentions that the real manifestation of this unity of faith is one body, one spirit and one hope in God. True knowledge of the Son of God is not only knowledge of Christ, but implies that believers must really know the Lord Jesus. In Ephesians 4:6 there are three things said by the apostle Paul regarding this true knowledge of the Son of God. First, know and believe that the Lord Jesus and the Father are one; second, believing that Christ is over 
the entire universe; third, believing that Christ is at work in all things that happen in this world. Full maturity is one of the results that God wants in the life of a believer, Richard F. Lovelace, in his work Dynamic of spiritual life, explains some of the conditions needed to guide people to grow into mature human beings in their spirituality, namely "having child consciousness in the position of God, he must be active in God's position and improve yourself in the formation of the character of Christ" [6] Growth according to the fullness of Christ is a process that should be experienced by the church and everyone who is born again in Christ. If a church is healthy, it will naturally grow. Christian Schwarz said, "The Church has growth potential with itself and this potential is a gift from God." [7] Rick Warren said, "The Church is a living organism, and everything that lives naturally grows. Our job is to remove the barriers that hinder growth. Healthy churches don't need tactics to grow, they grow naturally [8]. God naturally gives growth to every believer, when God's people as a living part of a church experience growth, the church will also grow automatically.

Based on the explanation above, it can be said that the complementary abilities of the shepherds based on Ephesians 4 should have an influence on the spiritual maturity of the congregations where the shepherds serve. An important question that needs to be answered is how much influence the ability of God's servants to equip has on the spiritual maturity of the congregation. In further discussion, the researcher will discuss the problem of the ability of the pastor to equip related to the four benchmarks of the spiritual maturity of the congregation. The research is limited to the Baptist churches in the Special Region of Yogyakarta so that it becomes the focus. The purpose of this study is to answer the question of how much influence the ability of the Pastor's Congregation in equipping the saints based on Ephesians 4 on the spiritual maturity of the Baptist church congregations in the Special Region of Yogyakarta.

\section{Method of ReSEARCH}

This study uses quantitative research methods in order to collect representative data that can be tested to answer the problems studied. In connection with the research on the Influence of the Ability of the Clergy Pastor in Equipping According to Ephesians 4 on the Spiritual Maturity of the Baptist Church Congregations in the City of Yogyakarta, the research method that will be carried out is to find out the influence of the ability of the congregational pastor in equipping the Spiritual Maturity of the Baptist Church congregations in the Special Region of Yogyakarta. In determining the number of samples in this study, the researchers used the general guidelines submitted by Andreas Subagyo [9], if the population is between 1001-5000 then the sample is $5 \%$. The sample is taken randomly at the Baptist church in the province of the Special Region of Yogyakarta. The data collection tool uses a Likert Scale from the level of strongly disagree to the level of strongly agree. The provisions are numbers $1-5$ and limit values from 0.1 to $5.0 \%$.

\section{RESUlt AND Discussion}

\section{A. Main Theme Ephesians 4}

Throughout chapters 1 to 3 , the apostle Paul discusses more about God's eternal purpose which is taking place in the history of human life. The image of man as the image of God which was damaged by the fall of man into sin is transformed into something new through the work of Christ's sacrifice on the cross. In chapter 4 , it discusses the new standards that guide the new society that has experienced redemption in Christ. Paul goes from explaining the urgency of what God does to what believers should do [10]. Article 4 contains practical guidelines that must be carried out, not only doctrines but have been entered into the application of life on a daily basis.

According to John R.W. Stott in chapters 4:1-16 there are four truths about unity that God wants His new church to enjoy, namely:

1. Christian unity depends on God's gracious love being manifested in our character and conduct.

2. Christian unity arises from God who is one.

3. Christian unity is enriched by the variety of gifts that God's people have received.

Spiritual Unity challenges us to grow into adults [11].

\section{B. Definition of Shepherd}

In general, the term shepherd refers to someone who is in charge and responsible for raising livestock. The Big Indonesian Dictionary defines a shepherd as a guide and caretaker of the flock [12]. Douglas tries to take the word shepherd literally, which refers to the past and present, namely a task that carries a calling with many demands, and that call is as old as Abel's call (Genesis 4:2) [13]. The person who is entrusted to carry out the duties as a shepherd is someone who has a position as a leader. Wongsome said that pastoral theology is also called the science of pastoral leadership [14].

Theologically, the term shepherd refers to acts of care and maintenance carried out by someone intensively that does not know time or situation and cannot be represented by another person. The Bible Dictionary explains that shepherding is a very important task in Israel for maintenance, this lies in one's dependence on sheep (livestock)" [15].

The explanation above will emphasize that the term 'shepherd' can be understood from two sides; the first refers to the task of caring for and maintaining livestock, pets; and second, in a spiritual sense, refers to the task that Allah has entrusted to someone to become a nurse or guardian of the soul of mankind (God's people).

In the context of Paul's teaching in Ephesians, the Lord Jesus is the head of all things (Ephesians 1:22), the whole church which is His body must grow in all things toward Him who is the head. Christ who is the head of the church and the Great Shepherd should be an example and a source of inspiration for all God's servants who are called to be a Shepherd of the Church. As Head of the Church, Christ chooses shepherds to carry out the task of shepherding the flock of God, namely the Lord's congregation in the church. In a church that is the body of Christ, the pastor is the leader who must guide and care for all the different parts of the body so that all can live in unity and grow towards spiritual maturity. This spiritual maturity is measured in the four main 
goals written in Ephesians 4:12, namely the unity of the faith, the true knowledge of the Son of God, full maturity and the level of growth that is in accordance with the fullness of Christ.

\section{The Gifts of the Shepherd among the Gifts of Ministry in Ephesians 4}

The gift of shepherding is one of the gifts given by Christ after His ascension to heaven. Pastoral care can not be separated from the duties and services of the church, because shepherding is an answer to everyone's need for warmth, full attention, and support. Good shepherding is needed to equip in efforts to grow and develop the church [16]. "If a pastor is called to serve, this means that God has commanded him to care for His people [17].

Ephesians 4:8 says that when Christ ascended on high, $\mathrm{He}$ took captives. Christ gave gifts to men. He gave His church apostles, prophets, evangelists, pastors and teachers. The five ministry gifts are offices given to the church after His ascension, hence they are referred to as post-ascension ministries. These gifts are given to equip the saints for the work of ministry, for the building up of the body of Christ, until all attain oneness of faith, true knowledge of the child of God, full maturity and a level of growth according to the fullness of Christ. Christ as the Great Shepherd gives the gift of shepherding to His church. Some writers combine pastors and teachers into one, so there are only four gifts of ascension ministry. A pastor/pastor is also a teacher, but a teacher doesn't have to be a pastor/pastor even though he teaches the word of God [18]. Although quite a lot of shepherds also have the gift of service as a teacher. Kevin J. Corner holds to the common opinion that between pastors and teachers in reality it is not always the same person, so the gifts of ascension are not just four but five gifts of ministry [19].

Researchers in the discussion of the gift of ministry hold that the pastor and teacher are not always the same person. Pastors are a special gift given by Christ the Great Shepherd to His church on earth to continue His work in caring for His flock.

\section{Shepherd's Ability in Equipping}

The word ability according to the Indonesian Dictionary means: ability; proficiency; strength: we strive with ourselves; riches [20]: Based on the above understanding, the ability of the pastor can be interpreted as the degree or level of ability/skill of a person in carrying out his pastoral duties. Shepherds in teaching not only transfer knowledge, but also transfer values and at the same time serve as mentors [21]. The word complete is a translation of the Greek word

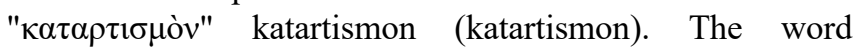
katartismon is a noun, masculine comes from the root word artizo which literally means complement. The word "equip" (katartismon) is a direct object that states the work done directly by the actor, namely equipping or training [22]. For the phrase "saints" There are two views of interpretation. The first view is that the saints in question are ministers given by Christ to equip believers for the use of their gifts in Christian service, so that by using both ministers and public ministry believers [23]. The second view is that these saints are believed to refer to the special ministry of those mentioned in Ephesians 4:11 namely apostles, prophets, evangelists, pastors and teachers, not the ministry in general [24].
Researchers in this case are more inclined to the first view. Thus what Paul means in Ephesians 4:12 in the context of the discussion on the gift of teaching is that the teacher has the duty to equip and train the saints for the work of the ministry. Saints in the sense of the special ministers mentioned in verse 11 and the more general Christian ministry. There are two things a pastor should do in equipping the saints so that service in the church can be done well, namely equipping them with knowledge, and equipping them with experience of faith.

\section{E. Equip with Knowledge (Ephesians 4:12, 20-21)}

One of the most important features that a pastor must give to his congregation is knowledge. Congregations with various backgrounds and specific gifts must be equipped with adequate knowledge about Christ who is the head and the unified source of the many different gifts that exist in the church. Understanding about Christ will make the congregation realize that it belongs to Christ who has been redeemed, placed in the church as part of the body of Christ, and given special gifts so that they can be involved and support the ministry to build the body of Christ. Another equally important knowledge is knowledge of the principles of righteousness in Christ. A good understanding of the principles of truth in Christ will make the congregation strong in belief, able to place themselves properly in the life of the congregation, and not be afraid to take steps and take a stand when dealing with people outside of Christ. When these two things are owned by the congregation, they will be more prepared to be involved in the process of building the body of Christ towards spiritual maturity. The following discussion will discuss in more detail the two complete sets of knowledge that a Pastor of the Church must give to his congregation, namely the introduction of Christ and the teaching of the truth in Christ.

Introduction to Christ (Ephesians 4:20)

In Ephesians 4:20 it is stated with the sentence "You have learned to know Christ". The word learning in Greek uses the word mantahano,

Mantahano, definition: an extension of the main verb, another form of matheo, used as an alternative in certain tenses. This word means to increase one's knowledge, to be increased in knowledge; to hear, to be contacted; to learn by using and practice becomes a habit, get used to it [25].

John RW. Stott (2003) argues that Christ is the essence of the teachings as well as the Teacher who teaches His disciples [26]. In line with this Peter T. O'Brien stated that in the Ephesians, Christ himself is the content of the teaching that the readers learn. As He was the subject of the preaching and teaching of the apostles [27]. Studying Christ means welcoming Him as a living person and shaped by His teaching [28]. Jesus chose His twelve disciples. He equips them to know God, to live according to His will and to be intimate with God's word so that they can carry out their ministry according to His will [29]. In the context of the pastor's task of equipping the saints in ministry, the congregation must be taught to know Christ with the aim of: first, to increase knowledge about Christ, both pastors and those being taught must have a more in-depth and complete knowledge of the person of Christ [30]. 
Ephesians 1:17 exhorts us to ask the God of our Lord Jesus Christ, that He may give the Spirit of wisdom and revelation to know Him properly. Because knowing Christ beyond all knowledge (Ephesians 3:19); second, having sensitivity to hear the voice of Christ. People who know Christ as mentioned in Ephesians 4:20 should have a sensitivity to hear the voice of Christ. The word hear in Ephesians is written 5 times in chapters $1: 13,1: 15,3: 2,4: 21$, and chapters $4: 29$. This shows that the word hearing is so important to be the attention of every congregation of God. Listening in the sense of raising our sensitivity to hear God's voice and the ministry God has given us (Ephesians 1:13, 3:2 and 4:21). But also listening in the sense that other people hear positive things about us. About our faith (Ephesians 1:15) and about our kind words to build up the Lord's church (Ephesians 4:29); Third, follow the customs of Christ. Knowing Christ requires concrete action [31]. In Ephesians 2:2-3 the apostle Paul reminded the recipients of the Ephesian letter that before accepting Christ they followed the ways of the world, living in the lust of the flesh, following the desires of the flesh and evil thoughts. God, who is rich in mercy, has given His great love to make us alive with Christ (Ephesians 2:4-5). Living together with Christ means we must also follow the habits that Christ modeled. So that every teacher and church of God can match the calling of service given by God according to Paul's advice in Ephesians 4:1.

Knowledge of the Truth in Christ (Ephesians 4:21b)

Ephesians 4:21b says "Because you have...received instruction in Him according to the truth which is manifest in Jesus." The word "because" that precedes does not indicate doubt but confidence and certainty [32]. The word teaching in Ephesians 4:21 is written with the Greek word didasko, the extended (causative) form of the main verb dao (study) which means:

to teach, to discuss with others to teach them, to give didactic sermons, to give instructions, to embed doctrine into one, to explain or explain something, to teach something. Based on this understanding, believers who receive the teachings of the truth in Christ will receive the word of God which is truth. They will be able to receive sermons, doctrines, explanations and teachings that come from the Word of God [33].

Donald Bridge and David Phypers (1973) argue as follows: "Regular Christian teaching whether through personal relationships, pulpit ministry, home services, or a combination of these and other ways is far more useful for strengthening the church than using other gifts." [34].

There are 4 functions of teaching the truth of God's word in the lives of believers, so that they can be equipped for every good deed. The 4 functions are:

First, the teaching function. Truth in Christ serves to teach. It has been started since the Old Testament times, God gave the command to teach the statutes and decisions spoken by God (Exodus 18:20, Leviticus 10:11, Deuteronomy 4:5,14, Deuteronomy 6:7). In the New Testament, the Lord Jesus also carried out teachings that came from the Word of God (Mark 12:14, Luke 20:21, 24:27, John 7:28). The Apostle Peter advised in the Letter of 1 Peter 4:11 "If anyone is speaking, let him speak as one who conveys the word of God...".
Michael J. Anthony (2001) argues that Bible study is at the heart of Christian education. The task of teachers is to write what is written in the Bible in the heart of every believer [35].

Second, the function declares an error. The truth in Christ serves to reveal error, because the word of God inspired by God is the truth [36]. God had the power to inspire truth to the writers of the Bible, so that the Bible is true. E.J. Young gives a definition of the inerrancy of the Bible as follows: "By this word we mean that the Scriptures have the quality of being free from error. They are excluded from the possibility of error, cannot be wrong. In all their teachings, they are perfectly in accord with the truth." [37]. Third, the function of improving behavior. Truth in Christ serves to correct behavior. God's Word in addition to declaring mistakes is also followed by guidance to correct behavior that is not in accordance with God's truth. For example, Ephesians 4:17-19 states the guilt of those who do not know God with their vain minds, dark understandings, far from the life of fellowship with God because of their stupidity and stubbornness of heart, lust, greed, doing unclean things. Then proceed with the guidance to leave the old man to be renewed in spirit and mind (Ephesians 4:23). " [38]. Put on the new man who was created according to God's will in true righteousness and holiness. The demand for correcting behavior in a new life is given in verses 25-16." [39].

Fourth, the function of educating people in the truth. Truth in Christ serves to educate people in righteousness. This is very clearly conveyed by the apostle Paul in Ephesians 4:21 ." [40]. that every church of the Lord which is the body of Christ should receive teaching in Him according to the real truth in Jesus. The teachings in Christ certainly come from the word of God. Christ in His ministry also always taught God's Word and educated people in God's way." [41]. Even when facing trials in the desert, He overcame the temptations of the devil by using God's Word. So it is clear that God's Word which contains the truth serves to educate people in the truth. ." [42].

\section{F. Field Research Results}

Based on the theoretical study." [43]. that has been submitted, in order to obtain data, the researcher makes a question questionnaire to be distributed and filled out by the sample. The initial filling is distributed to 30 trial respondents, then after the calibration process is declared valid which indicates that the instrument is reliable and can be used as a benchmark, it is continued by distributing the final instrument to 82 other respondents, the data has been determined according to the planned number of samples and based on the collected data. the researcher formulates the analysis description as follows:

\begin{tabular}{ccc}
\multicolumn{2}{c}{ TABLE I: VARIABLE EQUIPABILITY (X) } \\
\hline \hline \multicolumn{2}{c}{ Statistics } \\
\hline \hline \multirow{3}{*}{$\mathrm{N}$} & Variable Equipability (X2) \\
& Valid & 82 \\
& Missing & 0 \\
& Mean & 34.8293 \\
Median & 34.5000 \\
Mode & 34.00 \\
Std. Deviation & 2.85365 \\
Range & 11.00 \\
Minimum & 29.00 \\
Maximum & 40.00 \\
Sum & 2856.00 \\
\hline \hline
\end{tabular}


From the sample data of 82, an empirical score of 29 to 40 is generated, the mean is 34.8293 , the median is 34.5 , the mode is 34 and the standard deviation is 2.85365 .

\section{G. Test Requirements Analysis}

\section{1) Normality test}

Normality test was carried out for the variable (endogenous variable) and all indicators (exogenous variable) for the estimated proportion through the Blom formula for the P-P approach.

The plot is to find out whether the residual value under study has a normal or abnormal distribution. Residual values that are normally distributed when seen in the normal $\mathrm{P}-\mathrm{P}$ Plot Plot are standardized regression, then the data points/distribution are directed or are around the diagonal line and have no outliers. Likewise, the detrended data distribution for variables and indicators does not depict a certain curve and is collected around the horizontal line that passes through the zero point (detrended attachment). From the $\mathrm{P}-\mathrm{P}$ normality test, the standardized regression plot against SPSS 25 assistance is known as in Table II:

From the figure $\mathrm{P}-\mathrm{P}$ plot of Sub Variable X2 Ability to complete above shows that the data is normally distributed because the points (plot) follow a diagonal line.

\section{H. Linearity}

Linearity test is a test tool that is needed to find out the form of the relationship that occurs between the variables $\mathrm{X}$ and $\mathrm{Y}$. The linearity test is calculated against the linear regression test or deviation from linearity test. The linearity test was carried out to see whether the regression equation $Y$ $-a+b X n$ was in the form of a linear equation to find that the regression equation was linear or not with respect to the magnitude of the P-Value coefficient. Two variables are said to have a linear relationship if the linearity value is less than 0.05 or the deviation from linearity is more than 0.05 .

\section{Homogeneity}

The homogeneity test is intended to show that two or more groups of sample data come from populations that have the same variance. In regression analysis, the analysis requirement required is that the regression error for each grouping based on the dependent variable has the same variance (Table II).

From the results of SPSS 25 data anaylsis for the homogeneity test between variable $\mathrm{Y}$ and variable $\mathrm{X}$, it can be seen the $p$ value $>0.05$, it can be concluded that the data is taken from a homogeneous sample. Sub Variable $\mathrm{X}$ has a $\mathrm{P}$ Value of $0.458>0.05$, so it is said to be homogeneous (Table III).

TABLE II: TABELUJI LINIERITASY-X

\begin{tabular}{|c|c|c|c|c|c|c|c|}
\hline \multicolumn{8}{|c|}{ ANOVA Table } \\
\hline & & & Sum of Squares & $\mathrm{df}$ & Mean Square & $\mathrm{F}$ & Sig. \\
\hline \multirow{5}{*}{$\begin{array}{c}\text { KedewasaanRohaniJemaatGerejaBaptis } \\
\text { se-Daerah Istimewa Yogyakarta * } \\
\text { Kemampuanmemperlengkapi }(\mathrm{X})\end{array}$} & \multirow{3}{*}{$\begin{array}{c}\text { Between } \\
\text { Groups }\end{array}$} & (Combined) & 1863.742 & 11 & 169.431 & 14.234 & 0.000 \\
\hline & & Linearity & 1706.961 & 1 & 1706.961 & 143.402 & 0.000 \\
\hline & & $\begin{array}{l}\text { Deviation from } \\
\text { Linearity }\end{array}$ & 156.781 & 10 & 15.678 & 1.317 & 0.239 \\
\hline & \multicolumn{2}{|c|}{ Within Groups } & 833.233 & 70 & 11.903 & & \\
\hline & \multicolumn{2}{|c|}{ Total } & 2696.976 & 81 & & & \\
\hline
\end{tabular}

TABLE III: TEST OF HOMOGENEITY OF VARIANCES

\begin{tabular}{|c|c|c|c|c|c|}
\hline \multicolumn{6}{|c|}{ "Test of Homogeneity of Variances } \\
\hline & & $\begin{array}{l}\text { Levene } \\
\text { Statistic }\end{array}$ & df1 & df 2 & Sig. \\
\hline \multirow{4}{*}{$\begin{array}{l}\text { Kemampuanmemperlengkapi } \\
\text { (X) }\end{array}$} & Based on Mean & 1.656 & 17 & 61 & 0.077 \\
\hline & Based on Median & 1.020 & 17 & 61 & 0.451 \\
\hline & $\begin{array}{l}\text { Based on Median and with } \\
\text { adjusted df }\end{array}$ & 1.020 & 17 & 43.212 & 0.458 \\
\hline & Based on trimmed mean & 1.634 & 17 & 61 & 0.083 \\
\hline
\end{tabular}

\section{J. Hipotesis Testing}

Based on the tests of normality, linearity, and homogeneity, it can be concluded that the independent variable data (Variable X, Sub Variable X1, X2, X3) and the dependent variable (Variable $Y$ ) are normally distributed and there is a linear and homogeneous relationship between each variable and Sub Variable to be tested for the hypothesis. Because it is normally distributed, it is possible to test the hypothesis on the parametric rule. In accordance with the form of these variables and the form of the sociative hypothesis.

The hypothesis is proposed: The Ability of the Pastor in Completing Based on Ephesians 4:1-16 has a significant influence on the Spiritual Maturity of the Baptist Church in the Special Region of Yogyakarta. Testing of the hypothesis was carried out using several calculations, namely simple correlation analysis ( $\mathrm{r}$ yd) and regression significance test $(\mathrm{F}$ reg). Against using the SPSS 25 program, the correlation results of Variable $\mathrm{X}$ with Variable $\mathrm{Y}$ are obtained as shown in the Table IV.

Based on the correlational test using the Pearson formula, a correlation coefficient of 0.796 was obtained with a significance (P-Value) of 0.000 . this states that there is a strong and significant influence between the ability of the pastor in equipping $(\mathrm{X})$ based on Ephesians 4:1-16 on the Spiritual Maturity of the Baptist Church Congregations in the Special Region of Yogyakarta. 


\begin{tabular}{|c|c|c|c|}
\hline & & $\begin{array}{c}\text { Spiritual MaturityBaptist } \\
\text { Church Congregations } \\
\text { throughout the Special Region } \\
\text { of Yogyakarta }\end{array}$ & Equability $(\mathrm{X})$ \\
\hline \multirow{4}{*}{$\begin{array}{c}\text { KedewasaanRohaniJemaatGerejaBa } \\
\text { ptis se-Daerah Istimewa } \\
\text { Yogyakarta }\end{array}$} & Pearson Correlation & 1 & $0.796^{* *}$ \\
\hline & Sig. (2-tailed) & & 0.000 \\
\hline & $\mathrm{N}$ & 82 & 82 \\
\hline & Pearson Correlation & $0.796^{* *}$ & 1 \\
\hline \multirow[t]{2}{*}{ Kemampuanmemperlengkapi (X) } & Sig. (2-tailed) & 0.000 & \\
\hline & $\mathrm{N}$ & 82 & 82 \\
\hline
\end{tabular}

Based on the correlational test using the Pearson formula, a correlation coefficient of 0.796 was obtained with a significance (P-Value) of 0.000 . this states that there is a strong and significant influence between the ability of the pastor in equipping (X) based on Ephesians 4:1-16 on the Spiritual Maturity of the Baptist Church Congregations in the Special Region of Yogyakarta.

\begin{tabular}{cc} 
TABLE V: PEARSON RELATIONSHIP STRENGTH TABLE \\
\hline \hline Interval Koefisien & Level Interval \\
\hline \hline $0.800-1.000$ & In touch Very Strong \\
$0.600-0.799$ & Connected Strong \\
$0.400-0.599$ & Connect Enough \\
$0.200-0.399$ & Related Low \\
$0.000-0.199$ & Connected Very Low \\
\hline \hline
\end{tabular}

In order to be able to predict the contribution of the Capability of the Pastor in equipping (X2) based on Ephesians 4:1-16 to the Spiritual Maturity of the Baptist Churches throughout the Special Region of Yogyakarta, a linear regression method was tested, with the following results:

TABLE V: MODEL SUMMARY

\begin{tabular}{ccccc}
\hline \hline Model & \multirow{2}{*}{ R } & $\begin{array}{c}\mathrm{R} \\
\text { Square }\end{array}$ & $\begin{array}{c}\text { Adjusted R } \\
\text { Square }\end{array}$ & $\begin{array}{c}\text { Std. Error of } \\
\text { the Estimate }\end{array}$ \\
\hline \hline 1 & $0.796^{\mathrm{a}}$ & 0.633 & 0.628 & 3.51784 \\
\hline \hline
\end{tabular}

a. Predictors: (Constant), Equability (X2)

From the results of the regression between the variables $\mathrm{X}$ and $\mathrm{Y}$ above, it can be seen that the coefficient of determination of variance $\left(\mathrm{r}^{2}\right)$ is 0.633 which means that the Ability of the Pastor in equipping (X) based on Ephesians 4:1-16 contributes to the Spiritual Maturity of the Baptist Church in the Special Region of Yogyakarta by $63.3 \%$.

TABLE VI: ANOVA ${ }^{\mathrm{a}}$ TABLE

\begin{tabular}{|c|c|c|c|c|c|c|}
\hline & Model & $\begin{array}{l}\text { Sum of } \\
\text { Squares }\end{array}$ & Df & $\begin{array}{c}\text { Mean } \\
\text { Square } \\
\end{array}$ & $\mathrm{F}$ & Sig. \\
\hline \multirow{3}{*}{1} & Regression & 1706.961 & 1 & 1706.961 & 137.934 & $0.000^{\mathrm{b}}$ \\
\hline & Residual & 990.015 & 80 & 12.375 & & \\
\hline & Total & 2696.976 & 81 & & & \\
\hline
\end{tabular}

To be able to predict the magnitude of the contribution between the Ability of the Pastor in equipping (X) based on Ephesians 4:1-16 to the Spiritual Maturity of the Baptist Church congregations throughout the Special Region of Yogyakarta. The regression equation $\mathrm{Y}=\mathrm{b}+\mathrm{b}$ 1il $\mathrm{Y}=$ $34,264+1,609 \mathrm{X}$, and the value of the coefficient is equal to $34,264+1,609 \mathrm{X}$, with a value of $137000, \mathrm{~F}$ 93. The regression equation $\mathrm{Y}=34.264+1.609 \mathrm{X}$ means that if the score of the Ability of the Pastor in equipping (X) based on Ephesians 4:1-16 increases by one unit, the average score of the Spiritual Maturity of the Baptist Church in the Special Region of Yogyakarta will increase by 1.609 times from the current condition.

\begin{tabular}{|c|c|c|c|c|c|}
\hline \multirow[t]{2}{*}{ Model } & \multicolumn{2}{|c|}{$\begin{array}{c}\text { Unstandardized } \\
\text { Coefficients }\end{array}$} & \multirow{2}{*}{$\begin{array}{c}\text { Standardized } \\
\text { Coefficients } \\
\text { Beta }\end{array}$} & \multirow[t]{2}{*}{$\mathrm{t}$} & \multirow[t]{2}{*}{ Sig. } \\
\hline & B & Std. Error & & & \\
\hline (Constant) & 34.264 & 4.786 & & 7.159 & 0.000 \\
\hline $\begin{array}{c}1 \text { Kemampuanmemperlengkapi } \\
(\mathrm{X})\end{array}$ & 1.609 & 0.137 & 0.796 & 11.745 & 0.000 \\
\hline
\end{tabular}

Thus, from these two tests, it is stated that there is a strong and significant influence between the ability of the pastor in equipping $(\mathrm{X})$ based on Ephesians 4:1-16 on the Spiritual Maturity of the Baptist Church Congregation in the Special Region of Yogyakarta. So that the proposed hypothesis: The ability of the Pastor in equipping (X) based on Ephesians 4:116 has a significant influence on the Spiritual Maturity of the Baptist Church Congregations throughout the Special Region of Yogyakarta is declared accepted.

\section{CONCLUSION}

Based on the results of the research presented in the dissertation with the title "The Influence of the Capability of the Congregation Pastor in Leading based on Ephesians 4:116 on Spiritual Maturity of the Baptist Church Congregation throughout Yogyakarta Special Region" then get the following conclusions: $\mathrm{r}$ yd) and regression significance test ( $F$ reg) obtained a correlation coefficient of 0.796 to a significance (P-Value) of 0.000 . this states that there is a strong and significant influence between the ability of the 
pastor in equipping (X) based on Ephesians 4:1-16 on the spiritual maturity of the Baptist Church congregations in the Special Region of Yogyakarta. From the results of the regression between the variables $\mathrm{X}$ and $\mathrm{Y}$ above, it can be seen that the coefficient of determination of variance $\left(r^{2}\right)$ is 0.633 , which means that the ability of the Pastor in equipping (X) based on Ephesians 4:1 -16 contributes to the Spiritual Maturity of the Baptist Church Congregations in the Special Region of Yogyakarta 63.3\%.

\section{REFERENCES}

[1] Corner, Kevin.J., Jemaat DalamPerjanjian Baru, Penerbit Gandum Mas cetakanpertama, 296, 2004

[2] Departmenten Kependetaan Gabungan Gereja Baptis Indonesia, Tata Laksana Pejabat Gereja Baptis Indonesia, Jakarta, 66, 2017.

[3] R. F. Lovelace "Dynamic of Spiritual life" dalam B.S. Sijabat, Strategi Pendidikan Kristen, Bandung: Tiranus, 2016.

[4] C.A.Schwarz,"Ringkasan Pertumbuhan Gereja Alamiah" Jakarta:Yayasan Media Buana Indonesia, 34, 1999.

[5] R. Warren, "PertumbuhanGereja Masa Kini: Gereja yang mempunyai Visi-Tujuan," Gandum Mas, 21-22, 2000.

[6] A. B. Subagyo, "Pengantar Riset Kuantitatif dan Kualitatif." Bandung. Kalam Hidup, 2004.

[7] J. Stott, "The message of Ephesians," Inter-Varsity Press, 2014

[8] Suharso dan Ana Retnoningsih (ed.), KamusBesar Bahasa Indonesia (Semarang: WidyaKarya, 2011), 153.

[9] J. D. Douglas, "Ensiklopedi Alkitab Masa Kini Jilid II MZ," Jakarta: Yayasan Komunikasi Bina Kasih, 2011.

[10] P. Wongso, "Theologia penggembalaan." Malang: SAAT, 1983.

[11] W. R. F. Browning, "Kamus Alkitab (hc)," BPK Gunung Mulia, 2007.

[12] D. T. Simanjuntak, J. C. Santo. "Pengaruh Keteladanan Hidup Gembala Sidang Terhadap Pertumbuhan Gereja." KHARISMATA: Jurnal Teologi Pantekosta 2(1): 28-41, 2019.

[13] S. Masweli, C. Donald "Gembala sidang dan pelayanannya." Bandung. Kalam Hidup, 2002.

[14] P. P. Enns, "The Moody handbook of theology," Moody Publishers, 2008.

[15] A. M. Sardiman, "Interaksi Belajar Mengajar." Jakarta: Raya Grafindo, 2007.

[16] H. Sutanto, "Perjanjian Baru Interlinear Yunani-Indonesia dan Konkordansi Perjanjian Baru." Jakarta: LAI, 2004.

[17] P. T. O'Brien, "The letter to the Ephesians," Apollos, 1999.

[18] L. Eims, "Pemuridan Seni yang Hilang." Bandung: LLB, 2002.

[19] B.S. Sidjabat, "Sebuah Perspektifsecara Kristiani," Edisiketiga, 2017.

[20] T. H. Groome, "Christian religious education," BPK Gunung Mulia, 1980.

[21] D. Bridge, D. Phypers. "Spiritual gifts and the church," Inter-Varsity Press, 1973.

[22] M. J. Anthony, "Fondasi Pendidikan Abad 21, Penerbit Gandum Mas, 2001.

[23] J. L. C. Abineno, "Tafsiran Surat Efesus," Badan Penerbit Kristen, 1971.

[24] R. E. Coleman, "Rencana Agung Penginjilan," Bandung: Kalam Hidup, 1993

[25] K. O. Gangel, "Membina Pemimpin Pendidikan Kristen," Malang: Gandum Mas, 2001

[26] B. Hull, "Jesus Christ Disciplemaker, Yesus Kristus Sang Pembuat Murid," Literatur Perkantas, Jawa Timur, 2015.

[27] H. Usman, P. S. Akbar, "Metodologi Penelitian Sosial (Jakarta: PT Bumi Aksara.)," cet, 2000

28] L. E. Lebar, "Education that is Christian.," David C Cook, 1998

[29] L. Ryken, J. C. Wilhoit, T. Longman III, "Kamus Gambaran Alkitab," Surabaya: Momentum, 2011.

[30] M. Setiawani, S. Tong, S. Subeno, "Seni membentuk karakter Kristen," Lembaga Reformed Injili Indonesia (LRII), 1995.

[31] G. W. Peters, "Teologi Pertumbuhan Gereja," Penerbit Gandum Mas, Jawa Timur, cetakankedua, 2013

[32] N. Moh, "Metode Penelitian," Jakarta: Ghalia Indonesia, 2003.

[33] M. C. Tenney, "Survei perjanjian baru," Gandum Mas, 1995.

[34] T. Fo'arota, "Pengolahan Data Penelitian Perbandingan dan Hubungan," Jakarta: FKIP, 2006.

[35] M. A. Sumanto, "Metodologi Penelitian Sosial dan Pendidikan," Andi Offset Yogyakarta, 1995.
[36] M. A. Sumanto, "Pembahasan Terpadu Statistika \& Metodologi Riset (Buku1)", 2002.

[37] Sukamto, "Pendekatan Kuantitatifuntuk Penelitian," Enlightment Press, 2006.

[38] P. D. Sugiyono, "Metode Penelitian Administrasi," Alfabeta, Jawa Barat, 2012

[39] Saunders, Kristiani, "Integritas Seorang Pemimpin Kristen," Gandum Mas, Bandung, Jawa Barat, 1997.

[40] M. Rush, "Manajemen Menurut Pandangan Alkitab," Malang: Penerbit Gandum Mas, 2002.

[41] H. Johan, "Jurnal Penelitian ISLAM EMPIRIK."

[42] R. Comfort,"The Way Of The Master: Bersaksi Secara Sederhana dan Efektif Seperti Yang Dilakukan Yesus," Andi Offset, Yogyakarta, 2008.

[43] H. Haag, A. Kamus, "Penerbit Nusa Indah,” Flores, 1992. 